\title{
心理学的尺度の構成と歩行を対象とした評価方法の提示 各種動作時の快適性からみた上足床の変形性状の評価方法その 1 CONFIGURATION OF PSYCHOLOGICAL SCALES AND PRESENTATION OF EVALUATION METHOD FOR WALKING
}

Evaluation methods of no-shoes-floor deformation properties considering comfortableness human behavior Part 1

\author{
福田 眞太郎*1, 横山 裕*2 \\ Shintaro FUKUDA and Yutaka YOKOYAMA
}

\begin{abstract}
The final goal of our research is the establishment of evaluation methods of floor deformation properties considering comfortableness for various human behaviors. At the first, we defined the classification into walking and the others by floor deformation properties, based on the result of the sensory tests. At the next, we focused on human walking and examined evaluation methods of comfortableness for walking as the first step of our research. As the result, we defined that performance value compounding 2 factors about hardness and titubation of the floors can evaluate the comfortableness for walking.
\end{abstract}

Keywords : no-shoes-floor, deformation properties, comfortableness, floor hardness, titubation, evaluation method 上足床, 変形性状, 快適性, かたさ, 感触, 評価方法

1. はじめに

建築物の床は、人間が動作時に床に与える荷重に応じて、たわん だり、へこんだり、は衫返ったりする。このような床の鉛直方向の 変形性状は、心地よさ，動作のしやすさ，いたさなど、動作する人 間の快適性に大きく影響する。

一方、我が国の住宅や高齢者施設，幼児施設などの床は、靴を脱 いで使用寸る点が大きな特徴である。本研究では、これらの床を、 靴を履いて使用寸る下足床と反対の意味で、“上足床”と呼ぶことと する。上足床では、足裏のみが床と接触する歩行だけでなく、腰を 下ろす，座る，寝転がるなどの様々な動作が日常的に行われるため、 床と接触する身体部位や、接触時の床および身体部位の挙動などは、 著しく多様化する。しかし、これらの動作時の快適性からみた床の 変形性状の評価方法は、十分整備されているとはいい難い。

本報は、歩行を含む様々な動作時の快適性からみた上足床の変形 性状の評価方法を体系的に整備するための第一段階として、各種動作 時に感じる心地よさ，動作のしやすさ，いたさなどに関する官能検査 を実施し、構成される心理学的尺度相互の関係を検討するとともに、 かたさや感触に関する研究成果が比較的多く蓄積されている歩行を 対象に、これらの研究成果をさらに発展させ、歩行時の快適性からみ た変形性状の評価方法を確立した経過，結果を述べるものである。

\section{2. 目的, 範囲}

本研究は、様々な動作が行われる上足床を対象に、快適性からみ
た床の変形性状の評価方法を動作ごとに確立し、体系的に整備する ことを最終的な目的とする。また、本報は、本研究の第一段階として、 以下の 2 点を目的とする。

1）上足床で行われる様々な動作の中から、床の変形性状を評価する うえで代表的な動作を選定する際の基礎的知見を得る。

2) 上足床で行われる様々な動作のうち、かたさや感触に関する研究 成果が比較的多く蓄積されている歩行を対象に、2つの要因を複 合した変形性状の評価方法を確立する。

本研究で対象とする動作は、上足床で一般的に行われる動作全般と する。また、評価の観点は、心地よさ，動作のしやすさ，いたさなど動 作時の快適性と寸る。なお、高齢者施設で行われる介助動作や幼児施 設で行われる遊戯動作など、特殊な動作を対象とした評価方法は、本 研究で一般的な動作を対象とした評価方法を確立した後の課題とする。

本研究では、個々の上足床の具体的評価や、快適性の観点から優 れた上足床の開発，設計などは、範囲外とする。

\section{3. 既往の研究}

小野ら ${ }^{1), 2}$ は、歩行, 立位, 腰降し, 正座, 横臥回転の 5 種の動 作を対象に、動作時に感じる床のかたさの程度、およびかたさの適, 不適などに関する官能検查を実施し、心理学的尺度を構成している。 また、人間が歩行動作中の踵着地時に床に与える荷重を置換し、こ れと同等の荷重を与えた時の床の動的変形挙動を測定できる “床の かたさ測定装置”を開発している。さらに、装置による測定結果と

\footnotetext{
*1 東京工業大学環境 · 社会理工学院建築学系 助教・修士 (工学)

*2 東京工業大学環境 · 社会理工学院建築学系 教授·工博
}

Assis. Prof., Dept. of Architecture and Building Eng., School of Environment and Society, Tokyo Institute of Technology, M.Eng. Prof., Dept. of Architecture and Building Eng., School of Environment and Society, Tokyo Institute of Technology, Dr.Eng. 
心理学的尺度の関係に基づいて、床のかたさの定量的な評価方法を 確立している。

小野らが確立した評価方法は、当時普及していた様々な材料, 構法 の床に適用可能であった。ところが、その後、清掃性, 衛生性を維持 しつつ軽量床衝撃音遮断性を向上させる目的で “遮音フローリング” が新たに開発され、集合住宅を中心に普及してきた。これらの床の中 には、歩行時に「ぶよぶよする」,「ぐにゃぐにゃする」といった従来 にはない特異な感触が生起され、踏み心地が著しく悪いものがある。 しかし、小野らの評価方法には足裏で感じられる “感触” の要因が含 まれておらず、これらの床を適切に評価できないことが判明した。

そこで、横山ら ${ }^{3), 4)}$ は、小野らの方法では適切に評価できない床 を判別する方法について検討した。具体的には、床のかたさ測定装 置の一部を改良した “動的判別装置”を開発するとともに、床表面 の変形を 3 次元で測定できるシステムを併用し、装置で荷重を与え た時の載荷面とその周囲の床表面の動的変形挙動を測定した。その 結果、特異な感触の生起には、歩行動作中、踵が着地した後、動作 が進行し土踏まずや足裏前半部が接地した時点で感じる床表面の傾 きなどが大きく影響していることを明らかにし、装置による測定結 果に基づいて評価が低下する床を判別する方法を確立した。

以上より、歩行に関しては、小野らが確立したかたさの評価方法と、 横山らが確立した感触の影響で評価が低下寸る床の判別方法をあわせ て適用することにより、かたさと感触の 2 つの要因がともに考慮され た変形性状の評価が可能となった。しかし、この方法では、床のかた さ測定装置による測定と動的判別装置による測定をともに実施する必 要がある。ここで、後者は前者を改良した装置であり、床に与える荷 重は近似していることから、後者による測定結果のみに基づいて変形 性状を評価できる可能性が高いと推察できる。また、横山らの判別方 法は感触の影響による評価の低下の有無を判別するものであり、評価 の低下度合いが連続的に考慮されているものではない。よって、本研 究では、動的判別装置による測定結果のみに基づき、かつかたさと感 触の 2 つの要因が連続的に複合された評価方法を確立することとする。

一方、歩行以外の動作に関しては、遮音フローリングを含む様々 な変形性状の床を対象に、小野らおよび横山らの研究成果の適用の 可否を検討することとする。

\section{4. 研究方法}

本報における研究方法および手順は、以下の通りである。

1）上足床で行われる様々な動作の中から、床と接触する身体部位や、 接触時の床と身体部位の挙動などが多様となるよう留意し、本報 で対象とする動作を選定する。

2) 変形性状が異なる種々の試料床を製作して検査試料とし、検查員 を用いて、試料床上で 1) で選定した動作を行った時の快適性に関 する官能検查を実施する。検查結果から、尺度構成理論 $\left.{ }^{5}\right)$ にた がって心理学的尺度を構成する。

3）2）で構成した心理学的尺度相互の関係を検討し、上足床の変形性状 を評価するうえで代表的な動作を選定する際の基礎的知見を得る。

4) 小野らが開発した床のかたさ測定装置、および横山らが開発した 動的判別装置を用いて、2) で検查試料とした試料床の動的変形挙 動を測定する。

5) 4）の測定結果と、2) で構成した心理学的尺度の関係から、小野ら
および横山らの研究成果の適用の可否を検討するとともに、歩行 を対象に、かたさと感触の 2 つ要因が連続的に複合された変形 性状の評価方法を確立する。

\section{5. 各種動作時の変形性状に関する心理学的尺度の構成}

5.1 対象動作の選定

上足床で一般的に行われる動作は、床と接触する身体部位の観点 から、以下のように分類できる。

・足裏のみが接触する動作

歩行, 立位

・おもに足裏以外が接触する動作

腰下ろし, 立上り, 座位 (正座, 体育座り, 長座, あぐら), 卧 位 (仰向け, 側臥位, うつ伏せ, 肘立てうつ伏せ), 寝返り, 膝 歩き, 膝立ち

また、動作中の動きの有無の観点からは、以下のように分類できる。

- 動的な動作

歩行, 腰下ろし, 立上り, 寝返り, 膝歩き

・ 静的な動作 (姿勢)

立位, 座位 (正座, 体育座り, 長座, あぐら), 臥位（仰向け,

側臥位, うつ伏せ, 肘立てうつ伏せ), 膝立ち

以上に列挙した各動作を整理して、表 1 に示す。本研究では、こ れらの動作全てを対象とするのが理想的ではあるが、官能検査の規 模などを考慮すると現実的ではないことから、いくつかの動作を対 象動作として選定することとした。

はじめに、足裹のみが接触する歩行と立位に関しては、動作時に 感じるかたさ，感触からみた変形性状の評価がほぼ同様となること が横山ら ${ }^{3)}$ により明らかとなっていることから、立位での評価は歩 行で代替できるものと想定し、対象から除外することとした。

一方、おもに足裏以外が接触する動作に関しては、床と接触する 身体部位の類似性などから、以下の事項が推察された。

・体育座り, 長座, あぐらでは、いずれも臂部で感じるかたさ，感触 が評価に大きく寄与する。このうち、かたさ, 感触の差を最も感じ やすいのは、臂部にかかる体重の割合が最も大きいあぐらである。

・側臥位，うつ伏せでの接触部位は、寝返りでの接触部位に包含され ている。ここで、静的な動作 (姿勢) である側臥位，うつ伏せより、 動的な動作である寝返りの方が、かたさ，感触の差を感じやすい。

・膝歩きと膝立ちは、接触部位が一致している。ここで、静的な動 作 (姿勢) である膝立ちより、動的な動作である膝歩きの方が、か たさ，感触の差を感じやすい。

以上より、体育座り，長座での評価はあぐらで、側臥位，うつ伏 せでの評価は寝返りで、滕立ちでの評価は滕歩きで、それぞれ代替 できるもの想定し、対象から除外することとした。

最終的に選定した 9 種の対象動作を、表 1 に@で示す。

\section{表 1 上足床で一般的に行われる動作の分類と本研究の対象動作}

\begin{tabular}{|c|c|c|}
\hline & \multicolumn{2}{|r|}{ 床と接触する身体部位 } \\
\hline & 足裏のみ & おもに足裏以外 \\
\hline 動的な動作 & 歩行@ & 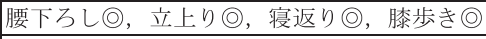 \\
\hline $\begin{array}{c}\text { 静的な動作 } \\
\text { (姿勢) }\end{array}$ & |立位 & $\begin{array}{l}\text { 座位 (正座@, 体育座り, 長座, あぐら@), } \\
\text { 卧位 (仰向け@, 側臥位, うつ伏せ, 肘立て } \\
\text { う伏せ@), 膌立ち }\end{array}$ \\
\hline
\end{tabular}


表 2 官能検査の概要

\begin{tabular}{|c|c|c|c|c|}
\hline 尺度構成手法 & \multicolumn{4}{|l|}{ 系列範ちゅう法 } \\
\hline 構成する尺度 & 心地よさ尺度 & 動作のしやすさ尺度 & 適性尺度 & 長期いたさ予測尺度 \\
\hline 質問事項 & \multicolumn{3}{|c|}{ この床は、かたさや感触の観点から、 } & この床は、長時間同じ姿勢をとり続けた場合、 \\
\hline 判断範ちゆう & $\begin{array}{l}\text { (7)非常に心地よい } \\
\text { (6)かなり心地よい } \\
\text { (5)やや心地よい } \\
\text { (4)どちらともいえない } \\
\text { (3)やや心地わるい } \\
\text { (2)かなり心地わるい } \\
\text { (1)非常に心地わるい }\end{array}$ & $\begin{array}{l}\text { (7)非常に動作しやすい } \\
\text { (6)かなり動作しやすい } \\
\text { (5)やや動作しやすい } \\
\text { (4)どちらともいえない } \\
\text { (3)やや動作しにくい } \\
\text { (2)かなり動作しにくい } \\
\text { (1)非常に動作しにくい }\end{array}$ & $\begin{array}{l}\text { (7)非常に適している } \\
\text { (6)かなり適している } \\
\text { (5)やや適している } \\
\text { (4)どちらともいえない } \\
\text { (3)やや不適である } \\
\text { (2)かなり不適である } \\
\text { (1)非常に不適である }\end{array}$ & 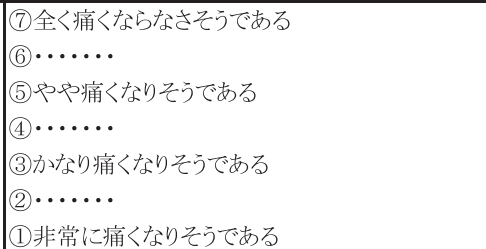 \\
\hline 動作 & \multicolumn{4}{|c|}{\begin{tabular}{|l} 
表1に示す 9 種の動作 \\
(動的な動作は心地よさ尺度, 動作のしやすさ尺度, 適性尺度、静的な動作(姿勢)は心地よさ尺度, 長期いたさ予測尺度を構成)
\end{tabular}} \\
\hline 検査試料 & \multicolumn{4}{|c|}{ 表3に示す 26 種の試料床 } \\
\hline 検査員 & \multicolumn{4}{|c|}{ 成人男性 10 名(年齢 $21 \sim 53$ 歳, 身長 $168 \sim 184 \mathrm{~cm}$, 体重 $53 \sim 99 \mathrm{~kg}$ ) } \\
\hline 履物および衣服 & \multicolumn{4}{|c|}{ 〈つ下および長袖, 長ズボンのジャージ } \\
\hline
\end{tabular}

\section{2 心理学的尺度構成のための官能検査概要}

5.1 で選定した 9 種の動作を対象に、官能検查を実施した。検査 の概要を、表 2 に示す。以下に、おもな事項について説明を加える。

\section{2.1 構成する尺度および尺度構成手法}

構成する尺度は、表 1 に示す動的な動作に関しては、動作時に感 じる心地よさの程度を表す “心地よさ尺度”、動作のしやすさの程度 を表す “動作のしやすさ尺度”、および心地よさと動作のしやすさを 勘案した総合的な適，不適の程度を表す “適性尺度”の 3 種とした。 一方、静的な動作 (姿勢) に関しては、前述の “心地よさ尺度” と、 長時間同じ姿勢をとり続けた場合に予想されるいたさの程度を表す “長期いたさ予測尺度”の 2 種とした。

尺度構成手法は、系列範ちゅう法 $\left.{ }^{5}\right)$ とした。判断範ちゅうは、表 2 に示す通りである。

\section{2.2 検査試料}

検査試料として、表面材，下地、および表面材と下地の間に挿入 する緩衝材の組合せが異なる、 26 種の試料床を製作した。試料床の 概要を表 3 に示す。表中、○で示す表面材, 緩衝材, 下地の組合せが、 検査試料とした試料床を表す。

検查試料の設定にあたっては、以下の点に留意した。

・実在する、あるいは今後開発されると思われる種々の材料, 構法の 床の範囲を包含するよう、多様な変形性状を有する試料床群とする。

・検査員が所定の動作を行うのに十分な大きさとする。

\section{表 3 試料床の概要}

\begin{tabular}{|c|c|c|c|c|c|c|c|}
\hline \multirow{2}{*}{\multicolumn{2}{|c|}{\begin{tabular}{|ll} 
& 分類 \\
下地 \\
\end{tabular}}} & \multirow{2}{*}{\multicolumn{3}{|c|}{$\begin{array}{c}\text { 直床 } \\
\text { RCスラブ }\end{array}$}} & \multicolumn{3}{|c|}{ 架構式床 } \\
\hline & & & & & \multirow{2}{*}{$\begin{array}{c}\text { パネル床 } \\
\mathrm{A}^{* 2}\end{array}$} & \multirow{2}{*}{$\begin{array}{c}\text { パネル床 } \\
\mathrm{B}^{* 3}\end{array}$} & \multirow{2}{*}{$\begin{array}{l}\text { 乾式 } \\
\text { 二重床 }\end{array}$} \\
\hline 表面材 & & 無 & $\begin{array}{c}\mathrm{UL} \\
12 \mathrm{~mm} /{ }_{9}\end{array}$ & \begin{tabular}{|c}
$\mathrm{UL}$ \\
$24 \mathrm{~mm} / \mathrm{I}^{\prime}$
\end{tabular} & & & \\
\hline \multirow[b]{2}{*}{ 畳 } & 畺42mm厚 (イ草製疊表，建材畳床 I 形 ${ }^{* 1}$ ) & 0 & & & o & & 0 \\
\hline & $\begin{array}{l}\text { 疊42mm厚(塩ビ製畳表，ポリウレタン } \\
\text { フォー製畳床) }\end{array}$ & 0 & & & 0 & & \\
\hline \multirow{3}{*}{$\begin{array}{c}\text { 塩ビ系 } \\
\text { 長尺シート }\end{array}$} & クッションフロアー3. $0 \mathrm{~mm}$ 厚 & 0 & & & 0 & 0 & 0 \\
\hline & クッションフロアー $3.2 \mathrm{~mm} /$ 厚 & O & & & & & \\
\hline & ヘテロジニアスシート $1.5 \mathrm{~mm}$ 厚 & 0 & 0 & & & & \\
\hline カーペット & カットパイルカーペット $5.0 \mathrm{~mm}$ 厚 & 0 & 0 & & 0 & 0 & 0 \\
\hline \multirow{2}{*}{ フローリング } & 複合フローリング15mm厚 & 0 & & & 0 & 0 & 0 \\
\hline & 遮音フローリング $17 \mathrm{~mm}$ 厚 (LL45相当) & 0 & & 0 & 0 & 0 & 0 \\
\hline \multicolumn{3}{|c|}{ 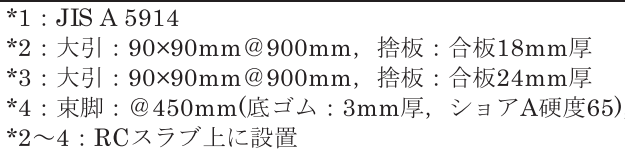 } & \multicolumn{2}{|c|}{$\mathrm{U}$} & ポリウ & タン系ア & $\begin{array}{l}\text { 多ーレイ } \\
\text { 武料床 }\end{array}$ \\
\hline
\end{tabular}

・検査員に疲労，倦㤐を感じさせない試料数とする。

・検査期間中、変形性状が変化しない試料床とする。

試料床の大きさは、それぞれ $900 \times 3600 \mathrm{~mm}$ とした。なお、動作位 置により変形性状が異なる架構式の試料床では、動作位置を指定した。

\section{2.3 検査員}

検查員は、同様の刺激を対象とした横山ら ${ }^{3)}$ の検查の結果、男女 による判断の差はほとんどないことが明らかとなったことから、健常 な成人男性 10 名 (年齢 $21 \sim 53$ 歳, 身長 $168 \sim 184 \mathrm{~cm}$, 体重 $53 \sim$ $99 \mathrm{~kg}$ ) とした。ここで、本検査では、高齢者や幼児なども対象とする ことが望ましいが、危険がともなうなどの理由で現実的には困難な ことから、検査は実施しないこととした。なお、高齢者や幼児など からみた評価は、健常な成人を対象とした検査結果から類推するの が、現段階では現実的な方法と考える。

\section{2.4 履物および衣服}

履物および衣服は、試料床との接触部位で感じる温冷感などの影 響をできる限り排除する観点から、木綿製のくつ下、および長袖, 長ズボンのジャージとした。

\section{3 官能検査経過, 結果および心理学的尺度の構成}

5.2 で述べた条件にしたがって、官能検査を実施した。検查は、検 查員の疲労を考慮し、動作ごとに別々の日に実施した。1つの動作の 検査に要した時間は、各検査員とも $30 \sim 60$ 分程度であった。また、 試料床の提示順序は、検査員, 動作ごとにランダムとした。検査の際、 検査員には、住居の居室などを想定して 動作すること、床のすべりや温冷感など 変形性状以外の要因は判断に入れない こと、疲れたらいつでも申し出ることを 教示した。

表 4 に、検查員の回答の分散分析結 果を示す。いずれの動作，検査項目で も、主効果の分散比が高度に有意となっ ており、かつ寄与率も大きいことか ら、検查試料による刺激に十分な差異 があったこと、本検查自体が有効であ ることがわかる。一方、個人差の分散 比も一部を除いて有意となっているが、 いずれも寄与率が主効果と比較して十 分に小さいことから、構成される尺度 
表 4 分散分析結果

\begin{tabular}{|c|c|c|c|c|c|c|c|c|c|c|c|}
\hline & \multicolumn{2}{|c|}{ 歩行 } & \multicolumn{2}{|c|}{ 腰下ろし } & \multicolumn{2}{|c|}{ 立上り } & \multicolumn{2}{|c|}{ 寝返り } & \multicolumn{2}{|c|}{ 膝歩き } \\
\hline & & 分散比 & 寄与率 & 分散比 & 寄与率 & 分散比 & 寄与率 & 分散比 & 寄与率 & 分散比 & 寄与率 \\
\hline \multirow{2}{*}{ 心地よさ } & 主効果 & $9.61^{* *}$ & $44.27 \%$ & $16.78^{* *}$ & $61.19 \%$ & $11.14^{* *}$ & $50.37 \%$ & $29.61^{* *}$ & $70.93 \%$ & $26.81^{* *}$ & $67.14 \%$ \\
\hline & 個人差 & $2.32^{*}$ & $2.44 \%$ & $3.16^{*}$ & $2.68 \%$ & $3.09^{*}$ & $3.32 \%$ & $8.50^{* * *}$ & $5.95 \%$ & $11.36^{* *}$ & $8.63 \%$ \\
\hline \multirow{2}{*}{$\begin{array}{l}\text { 動作の } \\
\text { しやすさ }\end{array}$} & 主効果 & $7.60^{* * *}$ & $36.56 \%$ & $11.87^{* *}$ & $53.11 \%$ & $5.71^{* *}$ & $33.49 \%$ & $19.70^{* * *}$ & $60.72 \%$ & $16.07^{* * *}$ & \begin{tabular}{|l|}
$56.98 \%$ \\
\end{tabular} \\
\hline & 個人差 & $4.05^{* k}$ & $6.08 \%$ & 1.88 & $1.37 \%$ & 1.10 & $0.23 \%$ & $9.66^{* * *}$ & $9.01 \%$ & $7.43^{* *}$ & $7.78 \%$ \\
\hline \multirow{2}{*}{ 適，不適 } & 主効果 & $8.97^{* *}$ & $41.47 \%$ & $13.13^{* \star}$ & $56.21 \%$ & $8.79^{* *}$ & $45.33 \%$ & $29.92^{* *}$ & $70.81 \%$ & $21.69^{* *}$ & $64.19 \%$ \\
\hline & 個人差 & $3.45^{* * *}$ & $4.59 \%$ & 1.41 & \begin{tabular}{|l|}
$0.61 \%$ \\
\end{tabular} & 1.24 & $0.44 \%$ & $9.13^{* * *}$ & $6.37 \%$ & $7.95^{* \star}$ & $6.90 \%$ \\
\hline & & \multicolumn{2}{|c|}{ 正座 } & \multicolumn{2}{|c|}{ あぐら } & \multicolumn{2}{|c|}{ 仰向け } & \multicolumn{2}{|c|}{ 时立てうつ伏せ } & & \\
\hline & & 分散比 & 寄与率 & 分散比 & 寄与率 & 分散比 & 寄与率 & 分散比 & 寄与率 & & \\
\hline \multirow{2}{*}{ 心地よさ } & 主効果 & $15.22^{* * *}$ & $48.81 \%$ & $18.55^{* *}$ & $56.50 \%$ & $22.22^{* *}$ & $59.64 \%$ & $23.65^{* *}$ & $63.16 \%$ & & \\
\hline & 個人差 & $13.63^{* *}$ & $15.61 \%$ & $9.76^{* *}$ & $10.15 \%$ & $12.13^{* *}$ & $11.25 \%$ & $8.93^{* \star}$ & $7.96 \%$ & & \\
\hline \multirow{2}{*}{$\begin{array}{c}\text { 長期いたさ } \\
\text { 予測 } \\
\end{array}$} & 主効果 & $16.04^{* *}$ & $49.13 \%$ & $14.70^{* *}$ & $55.35 \%$ & $22.93^{* *}$ & $61.88 \%$ & $23.46^{* *}$ & $63.69 \%$ & & \\
\hline & 個人差 & $15.48^{* * *}$ & $17.03 \%$ & $2.92^{*}$ & \begin{tabular}{|l|}
$2.79 \%$ \\
\end{tabular} & $9.74^{* *}$ & $8.88 \%$ & $7.80^{* * *}$ & $6.94 \%$ & & * : 危険率 $5 \%$ 以下 \\
\hline
\end{tabular}

は、検査員間に内在する個人差を内包するものの、各検查試料の変 形性状に対する平均的な判断を表す尺度として十分有効とみなすこ とができる。

以上より、尺度構成手法 ${ }^{5)}$ にしたがって、動的な動作 5 種 $\times$ 検查 項目 3 種 $=15$ 種、および静的な動作 $($ 姿勢 $) 4$ 種 $\times$ 検査項目 2 種 $=8$ 種、 計 23 種の心理学的尺度を構成した。

\section{4 心理学的尺度相互の関係の検討}

\subsection{1 評価の観点による心理学的尺度相互の関係の検討}

図1に、同一の動作で構成した 3 種(動的な動作の場合)または 2 種(静 的な動作 (姿勢)の場合）の尺度の関係の例を示す。図の（1）は歩行、 （2）は腰下ろし、（3）は正座、（4）は仰向けの場合の尺度の関係を示 したものである。図中、(1)〜 (7)で示寸破線は、官能検査に用いた判 断範ちゅう（表２参照）の尺度上の位置を表す。

図に示すように、（1）の歩行の場合、（2）～（4）と比較して、対応か ら外れている点がいくつかみられる。すなわち、評価の観点が異なる 3 種の尺度で、一部の試料床の序列が入れ替わっていることがわかる。 このことは、試料床の動的変形挙動の測定結果から心理学的尺度と対 応する物理的指標である “性能值”を設定する際、評価の観点ごとに それぞれ異なる性能值を設定する必要があることを意味している。

一方、図の (2) 〜 (4) に示寸歩行以外の動作の場合、対応から外 れている点は見当たらない。この結果は、他の動作でも同様であった。 このことは、 3 種または 2 種の尺度のうちいずれか 1 つの尺度と対 応する性能值を設定できれば、その性能值が他の尺度ともよい対応 を示すことを意味している。

\subsection{2 動作による心理学的尺度相互の関係の検討}

図 2 に、異なる動作で構成した尺度の関係の例を示す。図の(1) は歩行と歩行以外の動作、(2) は歩行以外の動作間での尺度の関係 を示したものである。図中の(1)～(7)の破線は、図 1 と同様である。

図に示すように、(1) の歩行と歩行以外の動作では、よい対応は 得られておらず、試料床の序列が大きく異なることがわかる。この 理由として、歩行時に床と接触する足裏と、歩行以外の動作時に床 と接触する足裏以外の身体部位では、接触時の床および身体部位の 挙動や、床の変形性状の感じ方が大きく異なることが考えられる。 このことは、少なくとも歩行と歩行以外の動作では、床の動的変形 挙動を測定する際の荷重条件を別々に設定しなければ、心理学的尺 度と対応する性能值は設定できないことを示唆している。

一方、（2）では、（1）と比較してよい対応が得られており、歩行以 外の動作間では、試料床の序列は大きくは変化していないことがわ かる。この結果は、他の歩行以外の動作間でも同様であった。この
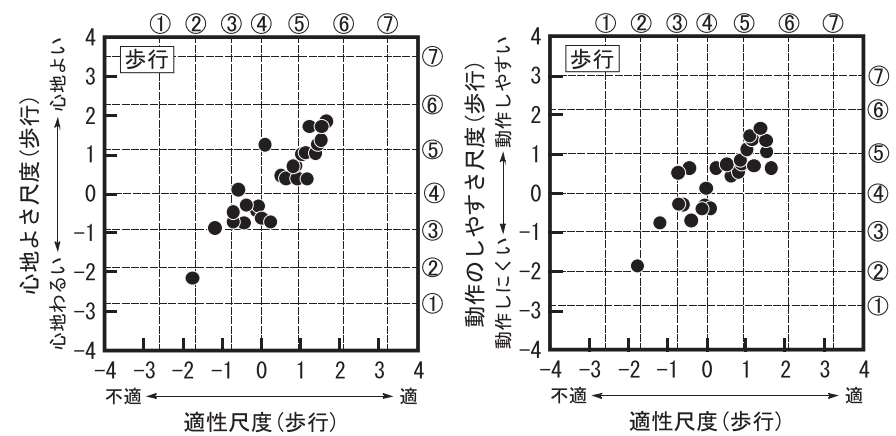

（1） 歩行の場合の尺度の関係
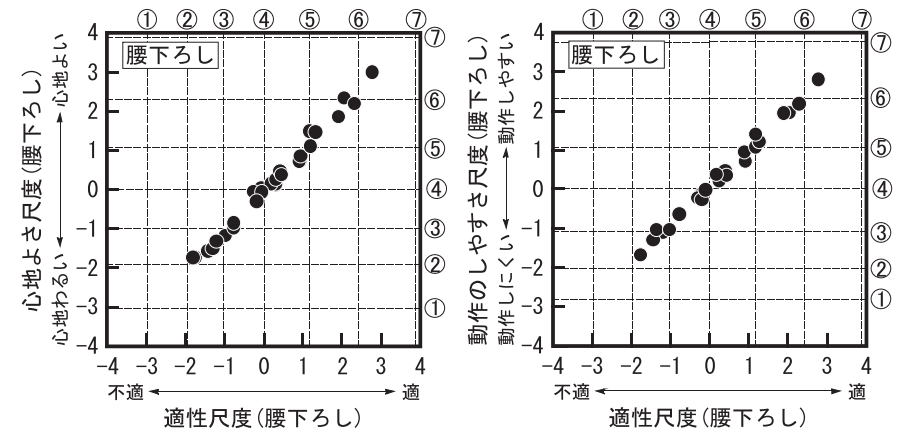

(2) 腰下ろしの場合の尺度の関係

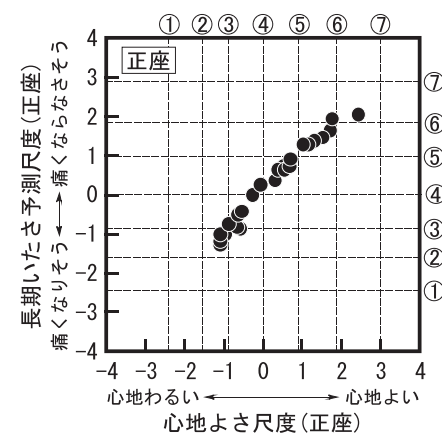

（3）正座の場合の尺度の関係

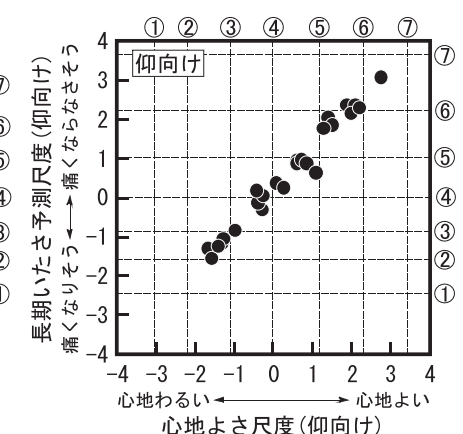

（4）仰向けの場合の尺度の関係
図 1 評価の観点による心理学的尺度相互の関係の例

理由として、歩行以外の動作では、床と接触する身体部位は異なる ものの、接触時の床および身体部位の挙動や、床の変形性状の感じ 方に類似性があることが想定される。このことは、対象とした歩行 以外の動作の中から 1 つの動作を選定し、この動作を置換した荷重 条件で床の動的変形挙動を測定することにより、歩行以外のいずれ の動作による心理学的尺度とも対応する性能值を設定できる可能性 が高いことを示唆している。 


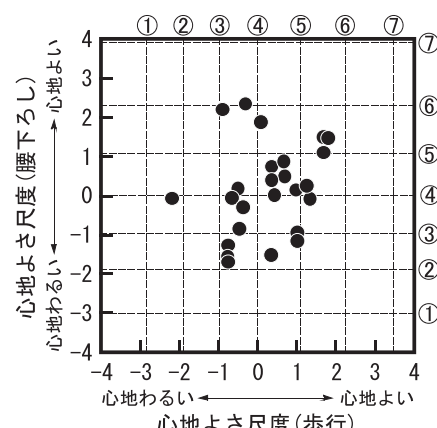

心地よさ尺度 (歩行)

（1）歩行と歩行以外の動作での尺度の関係の例
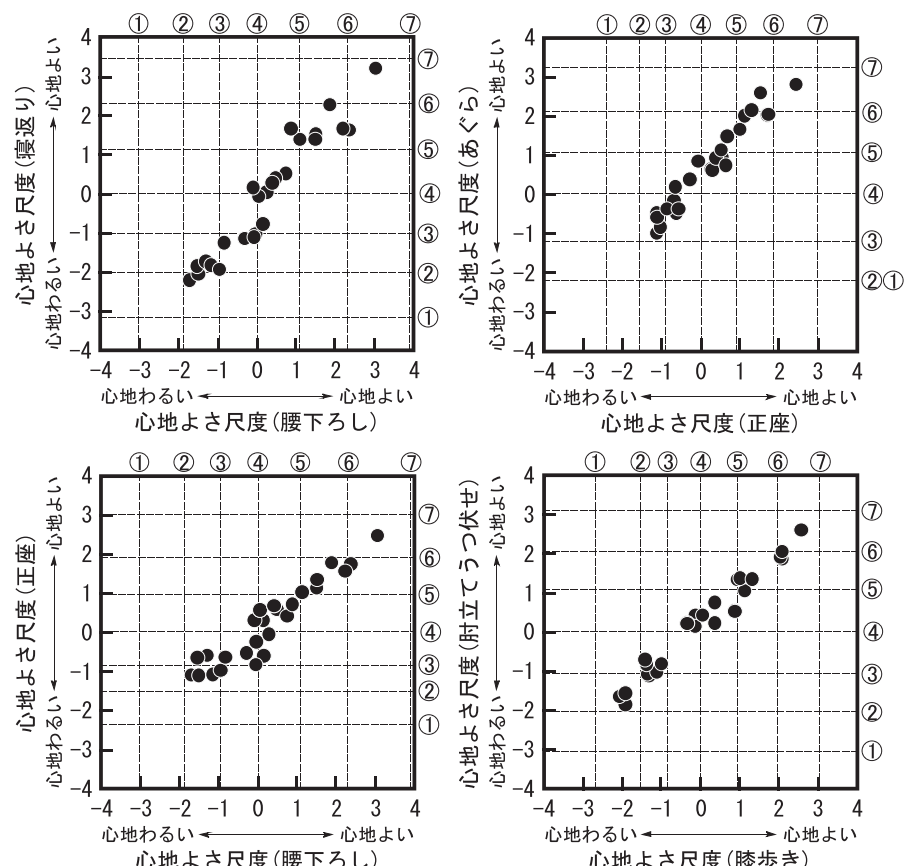

（2）歩行以外の動作間での尺度の関係の例

図 2 動作による心理学的尺度相互の関係の例

以上を要するに、本研究で選定した対象動作は、変形性状を評価 する観点から、足裏のみが接触する歩行と、おもに足裏以外が接触 寸る歩行以外の動作の 2 種に分類できることが、明らかとなった といえる。この結果は、足裏が、日常生活において、比較的小さい 面積で全体重を支えなければならない唯一の身体部位であり、歩行 のように不安定な動作を安全かつ効率的に行うために、他の部位に はない特有な感覚機能が必要と思われる部位であることを考慮する と、理解しや寸い。

\section{6. 試料床の動的変形挙動の測定および既往の研究成果の適用性の検討} 6.1 床のかたさ測定装置の概要

図 3 に、小野ら ${ }^{11,2)}$ が開発した床のかたさ測定装置の概要を示す。 本測定装置は、質量 $40 \mathrm{~kg}$ の重錘を減衰性の大きいゴムばね上に落下 させ、荷重板（直径 $70 \mathrm{~mm}$ ) を介して床に所定の荷重を与えた時の載 荷面の動的変形挙動を、装置に組み込んだ荷重変換器と、シャフト 頂部に取り付けた変位変換器で測定するものである。重錘は、下端 がゴムばね上端と接し、荷重変換器で測定される荷重が $3.0 \mathrm{kgf}$ となっ た位置から落下する。重錘落下前に床にかかる荷重は、この $3.0 \mathrm{kgf}$ に荷重板, 荷重変換器, 受け板, ゴムばね, シャフトの自重 $6.5 \mathrm{kgf}$

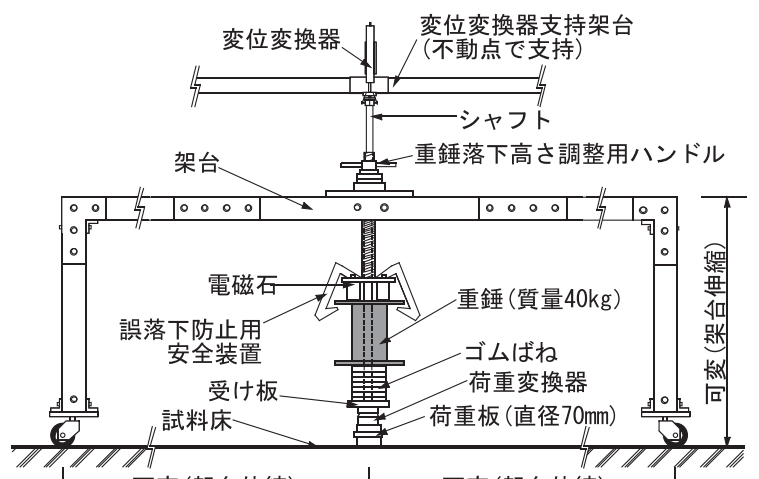

可変 (架台伸縮)

可変 (架台伸縮)

※床のかたさ測定装置と動的判別装置は、荷重板底面の形状および 荷重板, 受け板, ゴムばね, シャフトの材質が異なる

図 3 床のかたさ測定装置および動的判別装置の概要 ${ }^{1) ~ 4 ~}$

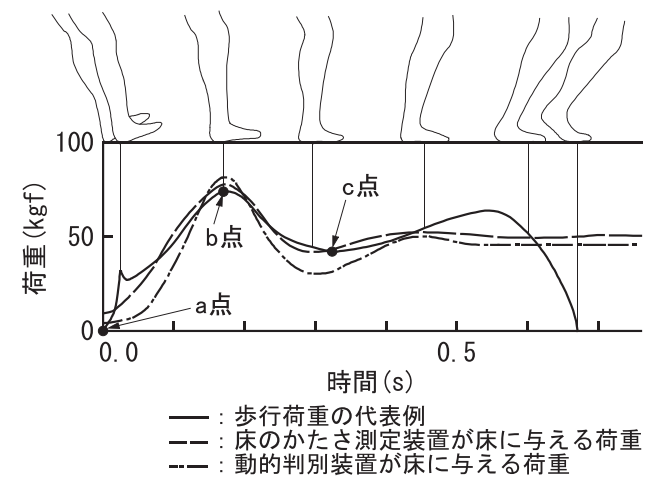

図 4 歩行荷重の代表例と床のかたさ測定装置 および動的判別装置が床に与える荷重 ${ }^{2)}$

を加えた $9.5 \mathrm{kgf}$ である。

図 4 に、本測定装置が床に与える荷重を、歩行者が床に与える荷 重 (以降、“歩行荷重”と記す) の代表例と比較して示す。図は、ほ ぼ剛とみなせる床を用いて測定した鈆直荷重を示したものである。 図より、破線で示寸本測定装置の荷重は、実線で示寸歩行荷重のうち、 足裏と床の接触開始時点 (図中 a 点) から、踵着地時に生じる極大值 (b 点) を経て、踏み出し動作への移行時に生じる極小值 (c 点) に至 る部分と近似していることがわかる。

\section{2 動的判別装置の概要}

「ぶよぶよする」,「ぐにゃぐにゃする」といった特異な感触が生 起する床を判別するためには、床の動的変形挙動を、載荷面周囲一 の面的な広がりを含めて、軽微な荷重領域から把握する必要がある。 横山ら ${ }^{3), 4)}$ は、このような考えに基づいて、床のかたさ測定装置の 一部を改良した動的判別装置を開発した。改良点は 2 点で、 1 点は、 載荷面周囲の変形に大きく影響すると思われる荷重板の底面形状を、 平面から踵と近似した曲率を有する曲面に変更した。もう 1 点は、 荷重板, 受け板, ゴムばね, シャフトの材質を変更して軽量化し、 荷重変換器とあわせた自重を $3.0 \mathrm{kgf}$ とした。また、重鍾は、下端が ゴムばね上端と接し荷重変換器で測定される荷重が $0.5 \mathrm{kgf}$ となった 位置から落下することとした。したがって、重鍾落下前に床にかか る荷重は、3.5kgf とした。

本判別装置が床に与える荷重を、図 4 に一点鎖線で示す。図より、 本判別装置による荷重が床のかたさ測定装置による荷重と近似して いることがわかる。 

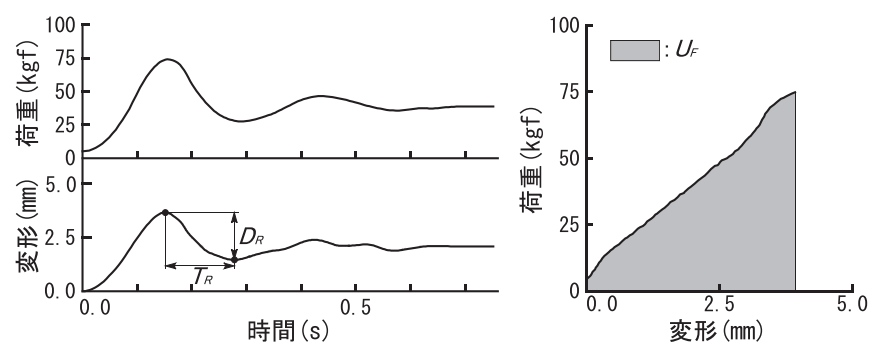

図 5 床のかたさ測定装置による測定結果の例 ${ }^{2}$

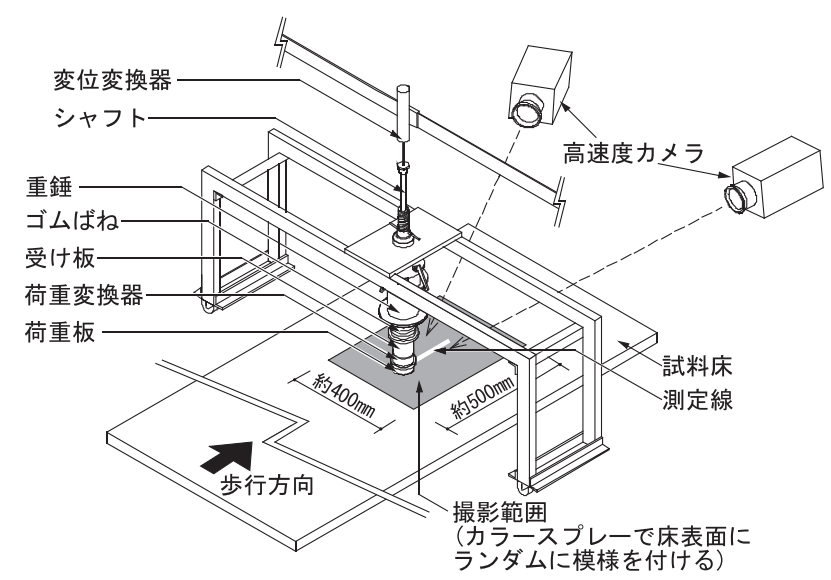

図 6 動的判別装置による測定状況 ${ }^{4)}$

\section{3 試料床の動的変形挙動の測定}

6.1 で述べた床のかたさ測定装置を用い、5. で官能検査に用いた 試料床の動的変形挙動を測定した。なお、試料床上の測定点は、官 能検査時の検查員の動作位置と整合するよう設定した。

図 5 に、床のかたさ測定装置で測定された荷重・時間曲線，変形・ 時間曲線と、荷重の立ち上がり時点から変形が最大に達する時点ま での荷重・変形曲線の例を示す。ただし、荷重および変形の值は、 床に荷重板, 荷重変換器, 受け板, ゴムばね, シャフトの自重がかかっ た状態を 0 としている。小野らは、図に示寸測定結果のうち、

$U_{F}(\mathrm{kgf} \cdot \mathrm{cm}):$ 変形が最大に達した時点までの変形エネルギー

$D_{R}(\mathrm{~cm}):$ 変形が最大に達した後の最大復元量

$T_{R}(\mathrm{~s})$ : 変形が最大に達した時点から最大復元量に達した時点までの 復元時間

から（式 1)にしたがって算出される $T$ を、人閒が感じる床のかたさ の程度を表す性能值として設定している。

$T=\log \left(U_{F}-8 \cdot D_{R} \cdot D_{R} / T_{R}\right) \quad \cdots \cdot($ 式 1$)$

$T$ は、值が大きいほど、その床はやわらかいと感じられることを 表す。よって、本研究では、各試料床の測定結果から $T$ を算出した。

つぎに、6.2 で述べた動的判別装置を用い、試料床の動的変形挙 動を測定した。図 6 に、測定状況を示す。図に示すように、本測定 でも、シャフト頂部に取り付けた変位変換器で、載荷面中心 (荷重 板の中心）の変形を測定した。加えて、本測定では、カラースプレー を用いて載荷面周囲の床表面にランダムに模様を付け、この模様を 2 台の高速度カメラで撮影した。撮影した画像を、2 台のカメラによ る画像の視差を利用して各点の変形を 3 次元で測定できるシステム を用いて解析し、載荷面周囲の床表面の変形を測定した。

図 7 に、動的判別装置で測定された荷重・時間曲線，変形・時間 曲線と、荷重の立ち上がり時点から変形が最大に達する時点までの
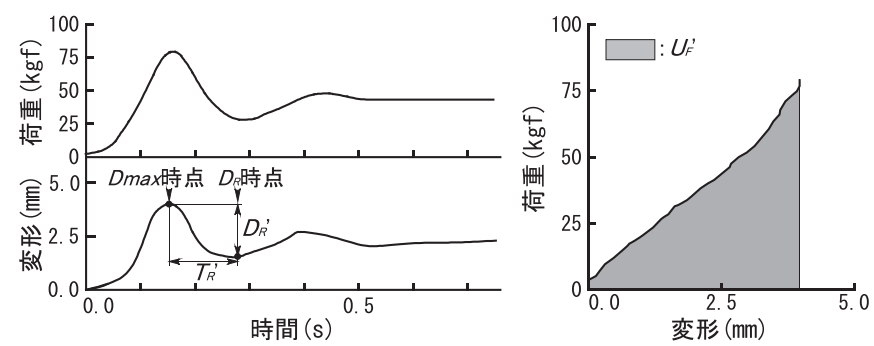

図 7 動的判別測定装置による測定結果の例

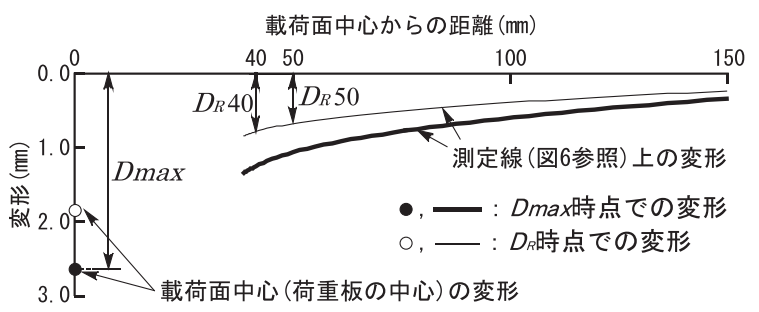

図 8 動的判別装置による載荷面中心および 測定線上の変形の測定結果の例

荷重・変形曲線の例を示す。本報では、以降、図に示すように、変 形が最大に達した時点を “D max 時点”、およびD max 時点後に変形 の復元量が最大に達した時点を “ $D_{R}$ 時点” と称する。各試料床の変形. 時間曲線から、D max 時点、および $D_{R}$ 時点における載荷面中心の変 形を求めた。一方、載荷面周囲の変形については、図 6 に示寸よう に載荷面中心から放射方向に測定線を設定したうえで、上記システ ムによる測定結果から、D max 時点、および $D_{R}$ 時点における測定線 上の変形を求めた。ここで、測定線は、官能検查時の検查員の動作 方向と整合するよう設定した。したがって、載荷面は歩行者の踵の 着地位置に該当し、測定線は土踏まずや足裏前半部の接地位置に該 当する。図 8 に、D max 時点、および $D_{R}$ 時点における、載荷面中心 と測定線上の変形の例を示す。

横山らは、図に示寸測定結果のうち、

$D \max (\mathrm{mm}): D \max$ 時点における載荷面中心の変形 (すなわち変形 の最大值）

$D_{R} 40(\mathrm{~mm}): D_{R}$ 時点における載荷面中心から $40 \mathrm{~mm}$ の位置の変形 $D_{R} 50(\mathrm{~mm}): D_{R}$ 時点における載荷面中心から $50 \mathrm{~mm}$ の位置の変形 から算出される以下の 2 つの值に基づいて、特異な感触の影響で評 価が低下寸る床を判別できることを明らかにしている。

$\left(D_{R} 40-D_{R} 50\right) / 10$ : 土踏まずや足裏前半部が接地する $D_{R}$ 時点で足裏 全体で感じる床表面の傾き

$D \max -D_{R} 40$ : 踵が着地する $D \max$ 時点で踵で感じる変形と、土踏 まずや足裏前半部が接地する $D_{R}$ 時点で足裏全体 で感じる変形の差

以上の 2 つの值を、前者を横軸, 後者を縦軸に取った判別図にプ ロットすることにより、評価の低下度合いを判別できる。図 9 に、横 山ら ${ }^{4)}$ が提示した判別図を示す。図の各点は、横山らが検討に用いた 試料床によるものであり、黒の点は官能検査の結果感触の影響で評価 が低下しなかった試料床、灰色の点は 1 範ちゅう程度低下した試料床、 白の点は 2 範ちゅう程度低下した試料床による点である。眓より、黒 の点と灰色の点の境界として破線を、また灰色の点と白の点の境界と して一点鎖線を得ることができる。すなわち、 $\left(D_{R} 40-D_{R} 50\right) / 10$ と 
$D$ max $-D_{R} 40$ の測定結果が破線より上側にプロットされる床は評価が 低下しない床、破線と一点鎖線の間にプロットされる床は 1 範ちゅう程 度評価が低下する床、一点鎖線より下側にプロットされる床は 2 範ちゅ う程度評価が低下寸る床と判別できる。よって、本研究では、各試料床 の測定結果から $\left(D_{R} 40-D_{R} 50\right) / 10$ と $D$ max $-D_{R} 40$ を算出した。

\section{4 既往の研究成果の適用性の検討}

図 10 に、6.3で算出した各試料床の $\left(D_{R} 40-D_{R} 50\right) / 10$ と $D \max -D_{R} 40$ を、図 9 に示した判別図にプロットした結果を示寸。図中の破線, 一点鎖線は図 9 と同一であり、破線より上側の点は 、破線と一点 鎖線の間の点はの、一点鎖線より下側の点は○で示してある。すな わち、○で示す試料床は感触の影響で評価が低下しない床、○で示 寸試料床は評価が 1 範ちゅう程度低下寸る床、○で示寸試料床は評 価が 2 範ちゅう程度低下する床と判別されたことを意味する。

図 11 に、5.3 で構成した歩行の場合の適性尺度と、6.3 で算出し た各試料床の $T$ の関係を示す。図中の(1)～(7)の破線の意味は図 1, 2 と同様であり、各点の記号の, ○、は、それぞれの試料床を図 10 にプロットして判別した結果にしたがっている。図より、○で示す 点は上に凸なる対応を示しており、図に点線で示寸ように、対応の 中心傾向を示寸曲線が得られることがわかる。また、○で示す点は 対応曲線より 1 範ちゅう程度、○で示寸点は 2 範ちゅう程度評価が

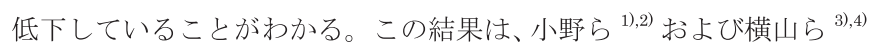
と一致しており、既往のかたさの評価方法、および感触の影響で評 価が低下寸る床の判別方法の適用性が確認できる。

一方、図 12 に、歩行以外の動作の場合の心理学的尺度と $T$ の関係 の例を示す。図に示すように両者は対応しておらず、5.4.2 で考察 した通り、歩行時の荷重を置換した装置では、歩行以外の動作時の 変形性状を適切に評価できないことが確認できる。なお、この結果は、 腰降し, 正座, 横臥回転時に感じるかたさの適, 不適も歩行時の荷 重を置換した装置で評価できるとした小野ら ${ }^{1,2)}$ の結果と異なってい る。この理由として、本報の試料床の中に、小野らの研究の後に普

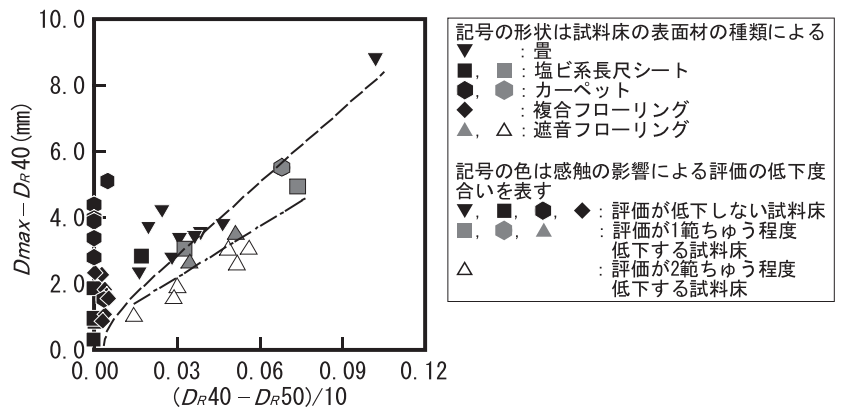

図 9 感触の影響で評価が低下する床の判別図 ${ }^{4)}$
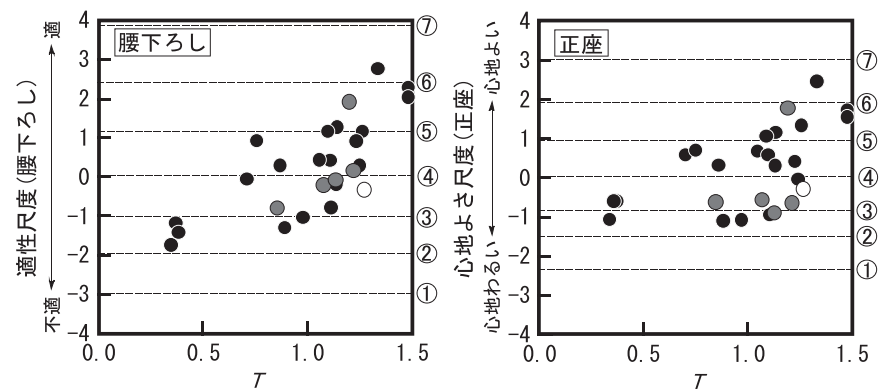

図 12 歩行以外の動作の場合の心理学的尺度と $T$ の関係の例

及した遮音フローリングや、変形の大きい乾式二重床, パネル床が 含まれていることが挙げられる。

\section{7. 歩行の場合の変形性状の評価方法の提示}

3.で述べた通り、歩行の場合を対象に、動的判別装置による測定 結果のみに基づき、かつかたさと感触の 2 つの要因が連続的に複合 された評価方法について検討した。

はじめに、床のかたさ測定装置で測定されるかたさの程度を表す 性能值 $T$ を、動的判別装置による測定結果で代替寸る方法について 検討した。具体的には、図 4 に示寸通り 2 つの装置による荷重が近 似していることから、図 7 に示す動的判別装置による測定結果から 床のかたさ測定装置で測定される $U_{F}, D_{R}, T_{R}$ に相当する $U_{F}{ }^{\prime}, D_{R}{ }^{\prime}$, $T_{R}^{\prime}$ を求め、(式 2$)$ にしたがって $T$ 'を算出した。

$$
T^{\prime}=\log \left(U_{F}^{\prime}-8 \cdot D_{R}{ }^{\prime} \cdot D_{R}{ }^{\prime} / T_{R}{ }^{\prime}\right) \quad \cdots(\text { 式 } 2)
$$

図 13 に、6.3 での測定結果から算出した各試料床の $T$ と $T$ ' の関 係を示す。図に示寸通り、両者はよい対応を示しており、 $T$ を $T$ ’で 代替可能であることがわかる。

一方、特異な感触の影響による評価の低下度合いは、図 9 および図 10 より、判別図の右下側にプロットされる床、すなわち $\left(D_{R} 40-D_{R} 50\right) / 10$ が大きく $D \max -D_{R} 40$ が小さい床ほど、大きくなる傾向があると 推察される。そこで、 $\left(\left(D_{R} 40-D_{R} 50\right) / 10\right) /\left(D \max -D_{R} 40\right)$ を用いて、 評価の低下度合いを表す性能值の設定を試みることとした。具体的 には、(式 3) で算出される $D$ の適用を検討した。

$$
\begin{aligned}
D= & \left.\left\{\left(\left(D_{R} 40-D_{R} 50\right) / 10\right) /\left(D \max -D_{R} 40\right)\right\}-0.011 \cdots \text { (式 } 3\right) \\
& \text { ただし } D<0 \text { の場合は } D=0 \text { とする }
\end{aligned}
$$

(式3) は、図 9 および図 10 の破線と近似した（式 4) で示す直線を 基準とし、それより上側にある点は評価は低下しないとみなし一律に 0 と寸る一方、下側にある点は $\left(\left(D_{R} 40-D_{R} 50\right) / 10\right) /\left(D \max -D_{R} 40\right)$ が大きくなるにしたがって評価が低下寸るとみなし、值が大きくな

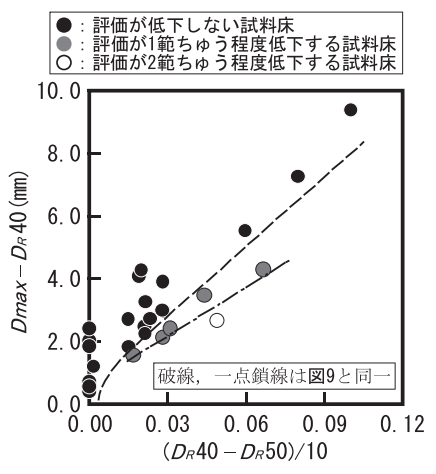

図 $10 \quad\left(D_{R} 40-D_{R} 50\right) / 10$ と $D \max -D_{R} 40$ の関係

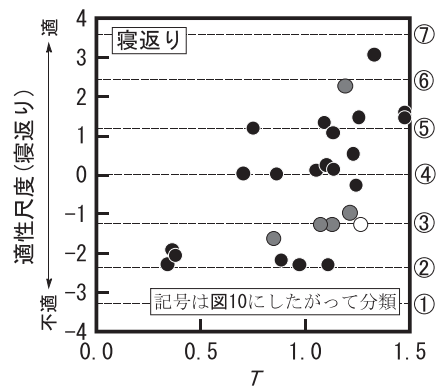

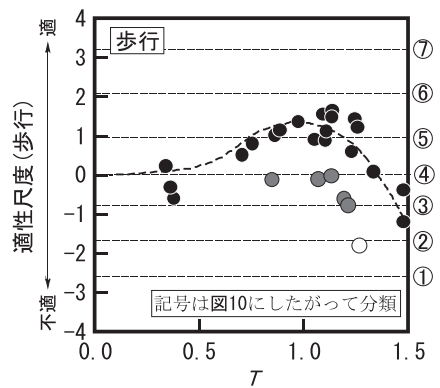

図 11 歩行の場合の適性尺度と $T$ の関係

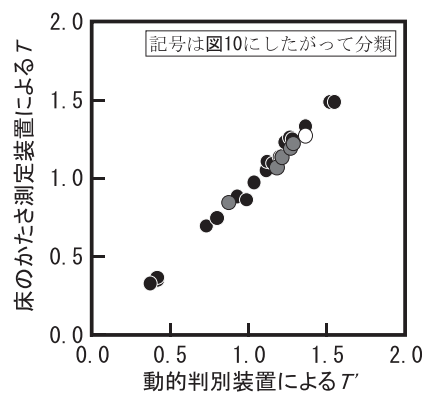

図 $13 T$ と $T^{\prime}$ の関係 


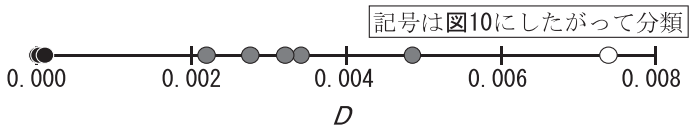

図 14 特異な感触の影響による評価の低下度合いと $D$ の関係
表 5 重回帰分析結果

\begin{tabular}{|c|c||c|c|c|c|}
\hline 心理学的尺度 & 性能値 & $\mathrm{A}_{1}$ & $\mathrm{~A}_{2}$ & $\mathrm{~A}_{3}$ & $\mathrm{~A}_{4}$ \\
\hline \hline 心地よさ尺度 & $Y_{1}$ & -3.951 & -4.694 & 9.720 & -358.9 \\
\hline 動作のしやすさ尺度 & $Y_{2}$ & -1.459 & -3.719 & 6.343 & -289.3 \\
\hline 適性尺度 & $Y_{3}$ & -3.583 & -5.298 & 10.143 & -322.5 \\
\hline
\end{tabular}
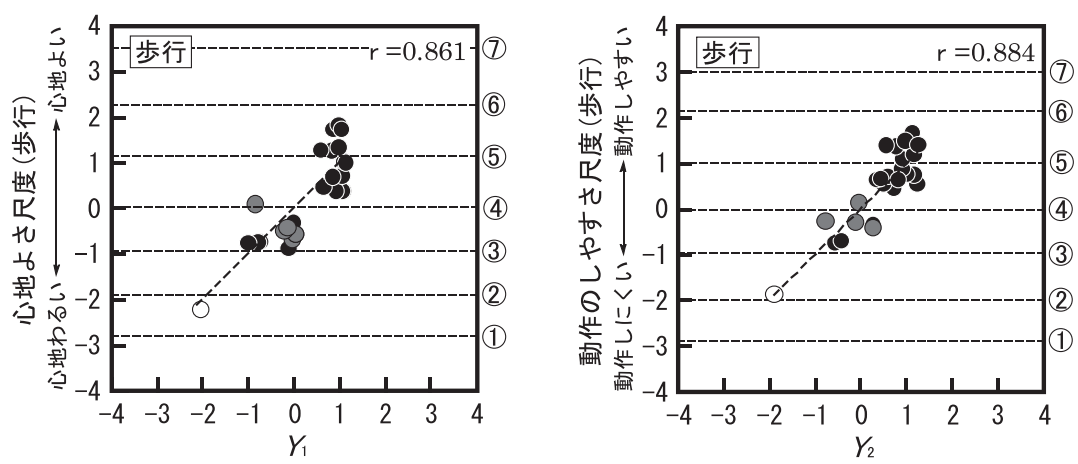

図 15 歩行の場合の心理学的尺度と $Y$ の関係

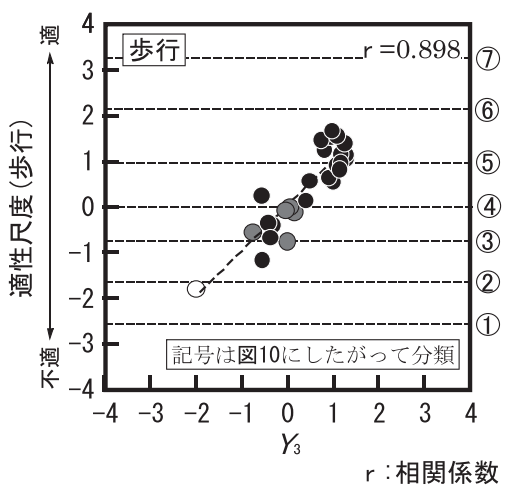

$r:$ 相関係数
るよう設定したものである。

$\left(\left(D_{R} 40-D_{R} 50\right) / 10\right) /\left(D \max -D_{R} 40\right)=0.011 \cdots$ ・式 4)

図 14 に、6.3 での測定結果から算出した各試料床の $D$ を、数直線 上にプロットして示す。図中の記号は、図 10 にしたがって分類した ものである。図より、数直線上の○，○，○の分布範囲は明瞭に区 別できることから、評価の低下度合いを $D$ で表示できる可能性が高 いことがわかる。

以上の検討結果に基づいて、 $T^{\prime}$ および $D$ を用い、歩行の場合の 心理学的尺度と対応する性能值を設定することとした。具体的には、 心理学的尺度を目的変数、 $T^{\prime}, T^{\prime}, D$ を説明変数とし、（式 5) に示 寸回帰式を仮定して、重回帰分析を行った。

$$
\begin{aligned}
Y= & \mathrm{A}_{1}+\mathrm{A}_{2} \cdot T^{\prime 2}+\mathrm{A}_{3} \cdot T^{\prime}+\mathrm{A}_{4} \cdot D \cdots \cdot(\text { 式 } 5) \\
& \text { ここで } D: \text { 目的変数 }
\end{aligned}
$$

$$
\mathrm{A}_{1} \sim \mathrm{A}_{4}: \text { 係数 }
$$

（式 5) で、T”について 2 乗と 1 乗の項を説明変数としたのは、図 11 に示すように床のかたさには最適值が存在することによる。

心地よさ尺度, 動作のしや寸さ尺度, 適性尺度の 3 種の心理学的尺 度ごとに重回帰分析を行った結果を、表 5 に示す。表に示すように、 係数 $\mathrm{A}_{1} \sim \mathrm{A}_{4}$ の値は心理学的尺度により異なっており、特に $\mathrm{A}_{2} \sim \mathrm{A}_{4}$ の割合が異なることから、 $T^{\prime 2}, T ', D$ が寄与寸る割合が評価の観点 ごとに異なっていることがわかる。この結果は、5.4.1での考察内 容と整合する。本研究では、以降、心地よさ尺度を目的変数とした 場合の $Y$ を $Y_{1}$ 、動作のしや寸さ尺度, 適性尺度を目的変数とした場 合の $Y$ をそれぞれ $Y_{2}, Y_{3}$ とする。(式 6) 〜 (式 8) に、 $Y_{1} \sim Y_{3}$ の 回帰式を示す。

$$
\begin{aligned}
& Y_{1}=-3.951-4.694 T^{\prime 2}+9.720 T^{\prime}-358.9 D \quad \cdots(\text { 式 6) } \\
& Y_{2}=-1.459-3.719 T^{\prime 2}+6.343 T^{\prime}-289.3 D \quad \cdots(\text { 式 7) } \\
& Y_{3}=-3.583-5.298 T^{\prime 2}+10.143 T^{\prime}-322.5 D \cdots(\text { 式 8) }
\end{aligned}
$$$$
\text { また、心理学的尺度と、(式 6)～(式 8)にしたがって算出される }
$$

$Y_{1} \sim Y_{3}$ の関係を、図 15 に示寸。図には、相関係数 $\mathrm{r}$ も示した。図 より、 $Y_{1} \sim Y_{3}$ が歩行の場合の変形性状の性能值として十分適用可 能であることがわかる。

なお、各回帰式から導出される $T$ ' の最適值は、心地よさ尺度が 1.035、動作のしや寸さ尺度が 0.853、適性尺度が 0.957 であり、3 種
の尺度の中では動作のしやすさ尺度が最も小さく、逆に心地よさ尺度 が最も大きく、適性尺度が中庸となっている。すなわち、動作のしや 寸さの観点から最適なかたさの方が、心地よさの観点から最適なかた さよりかたく、両者を勘案した適，不適の観点からはその中庸のかた さが最適となっていることがわかる。

以上より、本研究では、動的判別装置を用いて $T$, と $D$ を測定し、 $Y_{1} \sim Y_{3}$ を算出して図 15 と照合寸る方法を、歩行時の快適性からみ た上足床の変形性状の評価方法として提示する。

\section{8. おわりに}

上足床で行われる様々な動作時の快適性からみた床の変形性状の 評価方法を体系的に整備することを最終的な目的とし、その第一段 階として、各種動作時に感じる心地よさ，動作のしやすさ，いたさ などの関係を定量的に検討するとともに、歩行時の快適性からみた 変形性状の評価方法について検討した本報の結論をまとめると、以 下の通りである。

・上足床で行われる動作は、変形性状を評価する観点から、足裏の みが接触する歩行と、おもに足裏以外が接触する歩行以外の動作 の 2 種に分類できることを明らかにした。また、歩行以外の動作 間では、快適性からみた床の序列は大きくは変化しないことから、 これらの動作の中から 1 つの動作を選定し、この動作を置換した 荷重条件で床の動的変形挙動を測定することにより、各種動作に よる心理学的尺度と対応する性能值を設定できる可能性が高いこ とを明らかにした。

・動的判別装置で測定される $T$ 'で、床のかたさ測定装置で測定され るかたさの性能值 $T$ を代替できることを明らかにした。また、特 異な感触の影響による評価の低下度合いを表す性能值として、動 的判別装置による測定結果から算出される $D$ を設定した。さらに、 歩行時の心地よさ，動作のしやすさ、および両者を勘案した総合 的な適, 不適の程度を表す心理学的尺度と対応寸る性能值として、 $T ', D$ から算出される $Y_{1} \sim Y_{3}$ を設定した。以上より、動的判別 装置を用いて $T$ 'と $D$ を測定し、 $Y_{1} \sim Y_{3}$ を算出して心理学的尺度 との関係図（図 15）と照合する方法を、歩行時の快適性からみた 上足床の変形性状の評価方法として提示した。 
以上であるが、歩行以外の動作を対象とした場合の評価方法につ いては、次報で報告する予定である。

\section{謝辞}

試料床の作成にあたり種々御協力いただいた住宅メーカならびに 建材メーカの関係各位に、謝意を表します。なお、研究費の一部に 科学研究費補助金 (基盤研究 (B), 代表 : 横山 裕) を使用しました。

\section{参考文献}

1）小野英哲, 横山 裕, 大野隆造 : 居住性からみた床のかたさの評価方法に 関する研究, その 1 床のかたさに関する心理学的尺度の構成, 日本建築学
会構造系論文報告集，第 358 号，pp.1-9， 1985.12

2）小野英哲，横山 裕：居住性からみた床のかたさの評価方法に関する研 究，その 2 床のかたさ測定装置の設計・試作および床のかたさの評価指 標, 評価方法の提示, 日本建築学会構造系論文報告集, 第 373 号, pp.1-8, 1987.3

3）横山 裕, 高橋宏樹, 佐藤晋哉: 感触の影響で評価が低下寸る床の判別方 法の提示, 動作時の適性からみた床の変形性状の評価方法 その 1, 日本建 築学会構造系論文集, 第 75 巻, 第 658 号, pp.2087-2094, 2010.12

4) 横山 裕, 福田眞太郎：感触の影響で評価が低下寸る床の動的判別方法の 提示, 動作時の適性からみた床の変形性状の評価方法 その 2 , 日本建築学 会構造系論文集, 第 79 巻, 第 701 号, pp.877-885, 2014.7

5) J.P.Guilford, 秋重義治訳 : 精神測定法, 培風館, 1969 


\section{CONFIGURATION OF PSYCHOLOGICAL SCALES AND PRESENTATION OF EVALUATION METHOD FOR WALKING}

Evaluation methods of no-shoes-floor deformation properties considering comfortableness human behavior Part 1

$$
\text { Shintaro FUKUDA*1 and Yutaka YOKOYAMA*2 }
$$

\footnotetext{
${ }^{* 1}$ Assis. Prof., Dept. of Architecture and Building Eng., School of Environment and Society, Tokyo Institute of Technology, M.Eng.

${ }^{*}$ Prof., Dept. of Architecture and Building Eng., School of Environment and Society, Tokyo Institute of Technology, Dr.Eng.
}

"No-shoes-floor" mean the floors that person takes off his shoes in the popular Japanese houses or elderly facilities, we define it in our research. Due to behavior (walking, sitting, lying, etc.) of person on no-shoes-floor, body regions that touch to surface of floors or motions at each body regions are more multifarious than western style living. The final goal of our research is the establishment of evaluation methods of floor deformation properties considering comfortableness human behavior. We focused on human walking and examined evaluation methods of comfortableness for walking as the first step of our research.

The final goal of our research is the establishment of evaluation methods of floor deformation properties considering comfortableness human behavior. We focused on human walking and examined evaluation methods of comfortableness for walking as the first step of our research.

At the First, we selected typical 26 floors that have variety of deformation properties that are defined by our research. Using these floors, sensory tests had been carried out about comfortableness during various motions on the non-footwear floors, and psychological scales had been constructed using the test results. Then, the following 2 results were found due to examination of mutual relationships of the scales.

1) From a viewpoint of the evaluation about the comfortableness, the motions on no-shoes-floor are classified into 2 types. One is walking which only sole is in contact the floor surface during, and the other is various motions except walking. 2) The feelings of comfortableness about the various motions except walking are alike. Then, if a performance value corresponding to the psychological scale about a motion is set, this can also evaluate the comfortableness during the others various motions except walking.

At the Next, we execute evaluation method of floor hardness and dynamic discrimination method those typical evaluation method for human comfortableness. However these previous methods are complicated. So we tried to define the evaluation method which is more simple and appropriate than the previous method. In addition, the new method is able to measure the more detailed data. We call it as "evaluation method of floor deformation properties" (for walking). The evaluation method of floor deformation properties are constructed from the following 2 factors. These factors are measured by our developed machine that can reproduce loading condition of simulated walking action.

$T^{\prime}$ : performance value intends floor hardness

$D$ : performance value intends degree of decline of evaluation by titubation on floors

And, it was found that $Y_{1} \sim Y_{3}$ as the performance values calculated from compounding these 2 values are able to correspond to the psychological scales about the comfortableness for walking on the floors. Then, we presented the evaluation method for walking; the method is measuring $Y_{1} \sim Y_{3}$ by using device which can reproduce loading condition of simulated walking action, and applying to relationship diagram between the performance values and psychological scales.

The evaluation methods for the other actions will develop in next paper. 